\title{
Social Exclusion: Belonging and Not Belonging in the World System
}

\author{
Anthony H. Richmond
}

\begin{abstract}
The term "social exclusion" is defined. Research on social exclusion, undertaken in Britain, with particular reference to the situation of ethnic minorities and refugees is reviewed. It is argued that the phenomenon of social exclusion must be understood in a global context. Inequality, social exclusion, ethnic conflict, and terrorist activities, while not caused by globalization, have been greatly exacerbated by recent changes in the world system. The immigration and anti-terrorist measures adopted after 11 September are criticized, and policies that are needed to remedy the consequences of social exclusion are proposed.
\end{abstract}

\section{Résumé}

Le terme "marginalisation " est défini. Les recherches entreprises en Grande-Bretagne sur la marginalisation, tout particulièrement sur la situation des minorités ethniques et des réfugiés, sont passées en revue. On soutient que le phénomène de marginalisation doit être considéré dans un contexte global. Bien qu'il soit vrai que les inégalités, la marginalisation, les conflits ethniques et les activités terroristes ne découlent pas de la globalisation, ces phénomènes ont cependant été exacerbés par les changements récents intervenus dans le système mondial. Les mesures adoptées après le 11 septembre dans le domaine de l'immigration et de la lutte anti-terroriste sont critiquées et des politiques nécessaires pour remédier aux conséquences de la marginalisation sont proposées.

\section{Definition of Social Exclusion}

7 he term "social exclusion" was originally adopted by the European Commission to describe the inequalities, and the barriers to full participation in otherwise affluent societies, characteristic of countries experiencing a post-industrial revolution. ${ }^{1}$ Academic sociologists adopted the terminology, insisting that social exclusion is not the same as poverty. ${ }^{2}$ It means not sharing the same opportunities as the majority. This may be due to social isolation, as in the case of the elderly or disabled, or through discrimination based on nationality, language, "race," or religion. The denial of human rights to any category of persons is also a form of social exclusion.

In its most extreme form exclusion leads to genocide, i.e., the systematic large-scale extermination of a racial group or ethno-religious groups perceived as threatening the majority or a rival group. Since the atrocities in the former Yugoslavia, the term "ethnic cleansing" has been used to describe such attempts. Other less extreme manifestations lead to the partition of territory, the expulsion, exile, or deportation of minorities, and/or the repatriation of those previously allowed refuge or temporary asylum status. Struggles for power between rival ethnic groups have become militarized in the post-Cold War era, as formerly totalitarian regimes lose their dictatorial control and monopoly of weapons. Terrorism is one result. Victims of such political turmoil may flee the country but they do not necessarily find a welcome elsewhere.

While states reserve the right to control movement across borders and endeavour to prevent "illegal" immigration, migration occurs with or without legal sanction. People move from less developed to developed countries and regions, to perform menial or dirty work, supply field labour for agro-business, provide domestic services, or work in the sex trade. Many are victims of unscrupulous 
traffickers and smugglers. The victims of political and ethnic power struggles account for the large-scale movements of refugees that have occurred in eastern and central Europe, Africa, Asia, and Latin America. Developed countries in western Europe, North America, and Australasia are reluctant to give asylum to all those who flee persecution or seek to escape the economic and environmental disasters that occurred in the wake of such conflicts. Many displaced persons, as well as so-called "economic migrants," are being denied protection, because of a strict and narrow interpretation of the Geneva Convention criteria for full refugee status. Since September 2001, even more restrictive measures have been adopted in the name of improved security.

Various practices are used by wealthier countries to manage and control population movements. They involve classifying people according to their perceived eligibility to enter, or remain in, a particular territory. This is what has been called a form of "global apartheid." ${ }^{3}$ The instruments for the enforcement of global apartheid are interdiction, passports, visas, residence permits, work permits, denial of citizenship rights, including access to education, government-funded health and welfare services, etc. The forcible repatriation of refugees to so-called "safe third countries" is now standard practice, together with the deportation of "illegal" immigrants. These forms of state control of immigration are seen as a legitimate response to the destabilizing effects of large-scale migration. They are discriminatory by "race" because the majority of refugees and asylum applicants come from, and are obliged to remain in, Third World countries. Only a few actually reach Europe and North America.

In contrast, capital moves freely around the world, and entrepreneurs with money to invest have little difficulty obtaining residence permits, immigrant status, or even citizenship of the countries they wish to operate in. Special immigration programs for entrepreneurs, investors, and the highly qualified are examples of this. It is not so easy for those who bring only their labour, or who are deemed alien in language, culture, or religion. When not labelled illegal and imprisoned or deported, such workers find only low paid employment in manual jobs, often clandestine employment below the minimum wage.

The situation is currently aggravated by the structural changes that are taking place in the global capitalist system as a result of technological innovation, international competition, and the availability of cheap labour in developing countries, where tax and duty-free manufacturing enclaves are set up. Worldwide economic recession further exacerbates the situation. The dismantling of the "welfare state," privatizing of many services, and the removal of established "safety nets" and the substitution of "workfare," are all symptomatic of a shifting balance of power in the global system. The consequent vogue for "downsizing," and the deindustrialization of advanced societies, has ironic consequences. Blue-collar and other workers in declining industries experience extreme insecurity. There is a consequent reaction against employment equity and affirmative action programs, which previously favoured women and visible minorities. Young males with little education, whether immigrant or native-born, also see themselves as victims of systemic discrimination. When unemployment is high the result is alienation, xenophobia, and increasing support for a right-wing political agenda. Some young people are attracted to neo-fascist movements and, in certain cases, fundamentalist religions. Racial and ethnic prejudices are inflamed. Britain in the last decade provides a good example of this phenomenon.

\section{The U.K. Experience}

The term "social exclusion" gained currency in Britain under New Labour. It led to the establishment of several academic research units, as well as a government unit advising on social policies. ${ }^{4}$ The main focus of research at these institutions has been on youth policy, the chronically unemployed, the aged, single mothers, child poverty, and conditions in deteriorating housing estates with high crime rates. Surprisingly, until quite recently, the problems facing ethnic minorities have been largely neglected by researchers studying social exclusion. ${ }^{5}$

Studies in the U.K. have distinguished four dimensions of social exclusion, viz.: (1) exclusion from adequate income or resources; (2) labour-market exclusion; (3) service exclusion; and (4) exclusion from social relations. On all these dimensions ethnic minorities are more severely disadvantaged. One survey, carried out by a team of researchers in Birmingham, compared four groups: whites born in the U.K., compared with those of Bangladeshi, Pakistani, or Afro-Caribbean origin or parentage. The study showed that the ethnic minority groups were all over-represented in the low-income population. Nationally, households with $\mathrm{Pa}-$ kistani or Bangladeshi heads were also more likely to have no member in the workforce, high rates of unemployment, and the lowest household incomes. ${ }^{6}$ Other research in Britain has drawn attention to the widespread incidence of racism and Islamophobia. Institutionalized racism is evident in the police and prison services. There is discrimination in the housing and job markets. Since 11 September, Islamic communities have been rendered even more vulnerable.

Islamic Communities in the U.K.

Given the events of 11 September, and the apparent involvement of some British-born Muslims with the Taliban in 
Afghanistan, it is interesting to consider the situation of Islamic communities in that country. The Islamic population is estimated to be approximately nine hundred thousand, or 1.5 per cent of the population of the U.K. They are an ethnically diverse population, including immigrants from Africa, Asia, and the Middle East, their children born in Britain, and some British-born converts. The majority of Muslims are from Pakistan and Bangladesh, or are the U.K.born descendants of immigrants from those countries. Most of those of Pakistani and Bangladeshi origin are geographically concentrated in the poorest neighbourhoods in London, West Yorkshire, and Greater Manchester. Other Islamic centres are located in the Midlands, including Birmingham, Tipton, and Leicester. There is also a high degree of concentration of Islamic immigrants within these cities and metro areas. West Yorkshire and the Greater Manchester area (including Bradford, Oldham, and Burnley, where race riots occurred in the summer of 2001) accounted for 27 per cent of all Pakistani origin and 11 per cent of Bangladeshi. Residential segregation within these cities is also very marked.

A dramatic example of the consequences of social exclusion and deprivation in Britain were the race riots that broke out in the late summer of 2001, before the terrorist attacks of 11 September. They occurred in Bradford, Yorkshire, followed soon after by further violence in Oldham and Burnley. These were once thriving towns, built around the textile manufacturing industry in the north of England. They attracted large numbers of Indian, Pakistani, and Bangladeshi immigrants in the 1960s and 1970s at a time of low unemployment and labour shortages in Britain. There is now a large second generation, in their teens and young adult years. However, the post-industrial revolution and globalization left these towns and their inhabitants behind. As a consequence of globalization, textile manufacturing moved to the Third World. Poverty and unemployment are now exceptionally high and ethnic tensions severe in these towns in the north of England.

There is a huge gap between the relatively wealthy region of London and the south, and the northern towns with their crumbling housing stock and squalid neighbourhoods. In fact, the wealth gap between the rich southeast and the poor north is larger than the regional divide in any other European country. ${ }^{7}$ Midland towns which have Islamic minorities, such as Leicester and Tipton, have also experienced high unemployment following a downturn in the automobile industry. Manufacturing industries have declined in importance in Britain. In 1966 they accounted for 35 per cent of the labour force; by 1997 the proportion was only 25.6 per cent and is still falling. It is now close to 20 per cent. Textile industries were particularly affected by globaliza- tion and competition from Third World countries (including, ironically, Pakistan!). Consequently unemployment levels in these areas are very high. In some parts of Oldham and Bradford, where Asian immigrants are located, unemployment is as high as 40 per cent. Housing conditions in many neighbourhoods have deteriorated to the point of dereliction and imminent slum clearance.

A study was commissioned by the Rowntree Foundation, some time before the riots occurred. It concluded that:

[T] he Asian communities, particularly the Muslim community, are concerned that racism and Islamophobia continue to blight their lives resulting in harassment, discrimination and exclusion. People's negative attitudes about each other are formed and influenced in education, through the media, family and friends, and on the streets. ${ }^{8}$

By a cruel irony, the race riots broke out just as this report was about to be released. It included a long list of recommendations for improving community relations in Bradford. The riots were initiated by right-wing nationalists and led to several nights of violence, property damage, and clashes with the police. These were followed by similar violence in other northern towns. Since then a debate among policy makers has been concerned with the existence of a number of schools in which almost all the children attending from the immediate neighbourhood are of one ethno-religious background. The recent establishment of a separate school for Muslim girls is particularly controversial. It is feared that it will exacerbate existing barriers to communication and understanding between the Islamic community and others in the city. The existence of publicly funded schools run by the Anglican, Catholic, and Jewish faiths adds to the separation of young people of different ethno-religious background. Forthcoming legislation would permit the establishment of more faith-based schools. It has been severely criticized by those who fear even greater residential segregation and social isolation of Islamic communities and barriers to full inclusion of ethnic minority children.

Another report written after the riots had occurred highlighted the consequences of residential segregation. The researchers were particularly struck by the physical segregation and depth of polarization of the towns:

Separate educational arrangements, community and voluntary bodies, employment, places of worship, language, social and cultural networks, means that many communities operate on the basis of a series of parallel lives. These lives do not seem to touch at any point, let alone overlap and promote any meaningful interchanges. ${ }^{9}$ 
The problems facing Islamic and other immigrants, particularly recent refugees and asylum applicants, is not limited to Bradford, or other parts of Britain. Other European countries, including France and Germany, are facing similar problems of social exclusion and conflict. Various studies have noted the rise of anti-Islamic and anti-Semitic attitudes and behaviour in Europe and the consequential growth of political activism, as minorities address the problems created by economic insecurity and social exclusion. Transnational networks link ethnic, including Islamic, communities worldwide. Young men who feel excluded and alienated from society in one locality may be tempted to join wider extremist movements, or fundamentalist causes, inspired by the idea of 'jihad'; or, in the case of white youths, they may support the exaggerated nationalism preached by neo-fascist organizations. ${ }^{10}$

In the British government's own statements concerning "social exclusion" there is an emphasis on citizenship, which is understood to carry with it duties and moral obligations, as well as rights. The official response of the Home Office Minister, following the riots in Bradford and other northern towns, was to say that immigrants should be made to take an oath of allegiance to the Crown, overlooking the fact that most of those engaged in violent clashes were born in Britain. In fact, such a view was immediately endorsed by the extreme right-wing British National Party, whose members had been active in instigating the violence. The emphasis on "citizenship," and its responsibilities, also enables the government to "crack down" on alleged "welfare fraud," as well as on those it considers ineligible for the benefits of a welfare society, particularly so-called "illegal immigrants" and asylum seekers. When the latter are not imprisoned, or detained in segregated camps, they are eligible for a much lower rate of social benefits than the rest of the population in the U.K. They are also forced to disperse, from London and the southeast of England, to the run-down housing estates in the north of the country, including Scotland. In Glasgow, this led to clashes between asylum applicants and local residents, leading to the stabbing death of one asylum-seeker.

As well as denying refugee status to the majority of those who apply, the British government has also tried in vain to prevent illegal immigrants and asylum seekers from entering the country from France and other European countries. Many attempt to do so by stowing away on cross-channel ships, trains, and trucks and by endeavouring to walk through the Channel tunnel from camps run by the Red Cross in France. Punitive fines against those found guilty of carrying illegal migrants, knowingly or unknowingly, have been criticized by the courts as excessive and unfair. (The British government has since lifted the penalties on the Euro-Tunnel). When caught on the English side of the Channel, migrants are held in detention centres (mostly former prisons). Those considered to have a prima facie case for refugee status (including in some cases unaccompanied children) are then sent to public housing estates in the north, pending the outcome of their refugee hearing, which can take months, or years if there is an appeal. A new Immigration Bill, introduced in April 2002, closes so-called loopholes in immigration and asylum law and introduces tough penalties for trafficking. Some of its key provisions are summarized in Chart 1. In the House of Lords, the bill was amended in order to improve housing provision for asylum seekers, prevent school segregation, and limit the grounds for deportation. However, it is expected that the government will use its majority in the House of Commons to overturn these amendments when the bill returns to the Commons for final approval.

\section{Global Dimension of Social Exclusion}

What is lacking in the usual definition of "social exclusion" is a recognition that countries such as Britain, the rest of the European Union, Canada, the United States, and other OECD countries are the affluent part of a world system. It is true that there are huge gaps between the rich and the poor within these advanced industrial countries. Visible minorities and recent immigrants are particularly likely to fall below the poverty line, however that is defined. Single mothers and the elderly are also vulnerable. However, the inequalities, which undoubtedly exist within these countries, pale in significance when compared with the inequalities between them and the rest of the world. Poverty in Britain, Canada, and other OECD countries is a relative concept and has no similarity to the absolute levels of deprivation experienced in the Third World (see Chart 2). The average gross domestic product per capita of the advanced industrial countries is $\$ 27,510$. This compares with $\$ 23,557$ for the U.K. and less than $\$ 500$ for Africa south of the Sahara and $\$ 460$ in south Asia. Even within the NAFTA region there are huge discrepancies. The GDP per capita for the U.S. is $\$ 33,900$, compared with $\$ 25,900$ for Canada and only $\$ 8,100$ for Mexico. The average for the whole of Latin America and the Caribbean is only $\$ 3,860$.

There is a close connection between low levels of income and the incidence of violent conflict, including civil war. Afghanistan, in particular, has experienced both external and internal conflict, including invasion by the Soviet Union and, more recently, the United States and its allies, in the "war against terrorism." It is not surprising that Afghanistan has been the source of the largest concentration of refugees, located in camps in Iran and Pakistan. The numbers of internally displaced persons and refugees grew even more as a result of American bombing. 


\section{Chart 1}

U.K. Nationality, Immigration and Asylum Bill, 2002

- Power to search and detain suspected illegal immigrants

- Power to remove children born in U.K., if parents entered illegally

- Restricted rights of appeal against deportation

- New ID measures to be introduced at border controls

- Physical recognition equipment authorized to discover false identities

- New criminal offence of people trafficking for prostitution, \& assisting illegal immigration

- Maximum penalty for harbouring unlawful immigrant up to 14 years

- New tiered system of Centres to house asylum seekers

- Limits obligation of local education authorities to provide schooling for children in Centres

- Airlines must obtain clearance for passengers before they begin journey to U.K.

- Banks, employers and public authorities must share information concerning suspected illegal entrants

- New citizenship ceremony and oath of allegiance

- New language, and knowledge of life in the UK, qualification for naturalization

- Power to deprive citizenship, if person has done anything seriously prejudicial to the vital interests of the U.K. (If the Secretary of State deems information should not be made public, right to appeal limited.)

Chart 2

Gross national income per capita: Year 2000

\section{U.S. dollars}

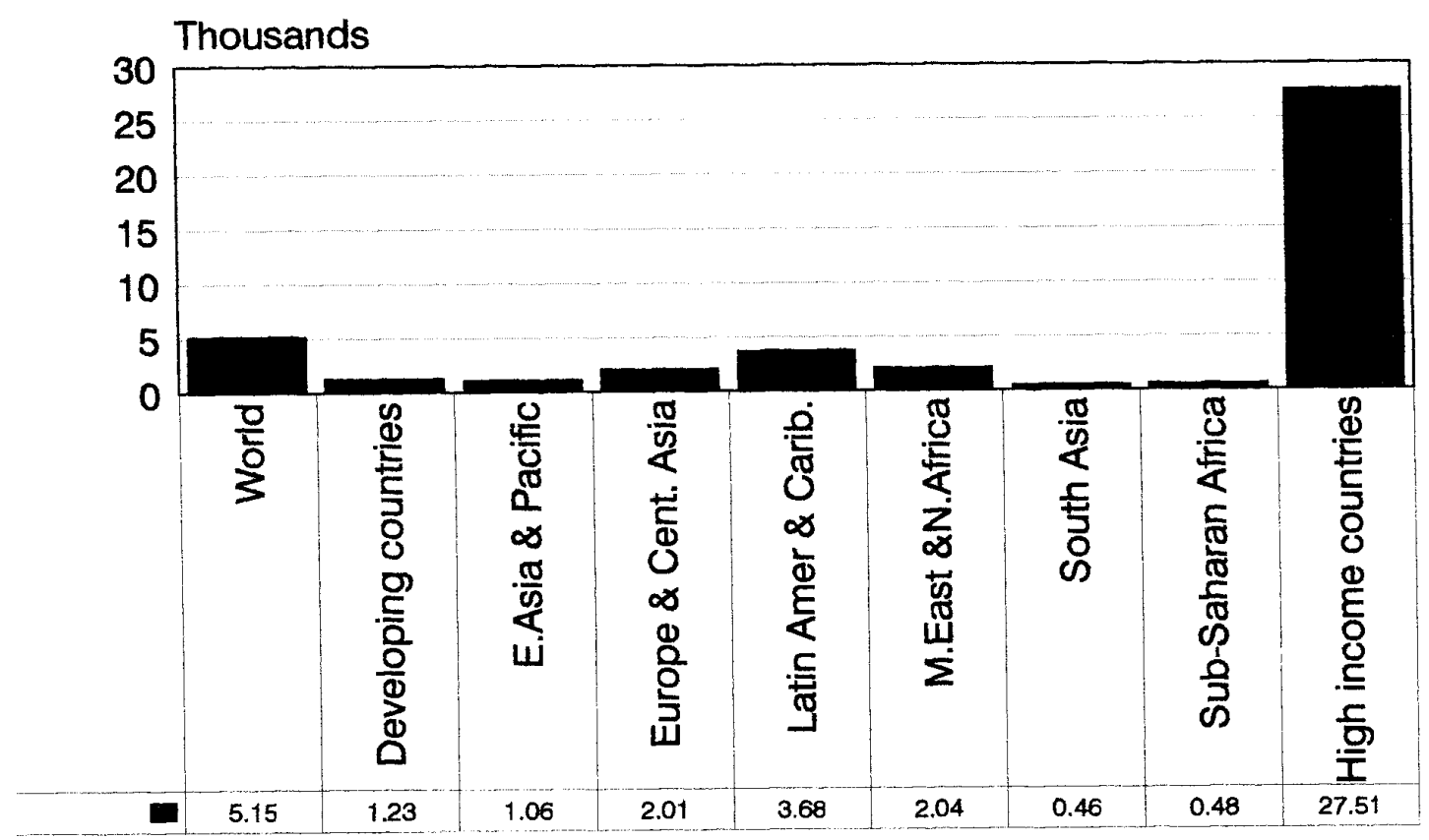

World Bank estimates 
When all those of concern to the UNHCR are considered, including the internally displaced and returnees, Asian countries carry the heaviest burden, followed closely by Africa and the Middle East. There are an estimated 11.7 million "Convention" refugees and many externally and internally displaced persons today. Thus the UNHCR reported nearly 22 million persons of concern to that agency in 2001 (See Chart 3). To these must be added another 3.8 million Palestinians under the care of the UNRWA. Even before the U.S.-led war in Afghanistan that country was the largest single source of refugees in the world. There were 3.6 million Afghan refugees mainly located in camps on the borders with Pakistan and Iran. There were a further 750,000 displaced persons in Afghanistan in January 2001. The numbers have grown substantially since the war. The number of asylum seekers from Afghanistan reaching the west is small by comparison.

Refugees and asylum applicants are particularly vulnerable as a consequence of exclusion from fundamental human rights and the benefits of a welfare society. The number of asylum applications submitted in advanced industrial countries fluctuates annually as do the numbers accepted for full Convention refugee status, or other (mainly temporary) humanitarian status. The Convention status acceptance rate in the European Union averages 14 per cent. This compares with 46 per cent in Canada. The number of asylum seekers applying in Britain rose until the year 2000 when there were 80,315 about whom decisions were finalized, of whom 12 per cent received full refugee status and 11 per cent "exceptional leave to remain," i.e., temporary status. The number of asylum seekers fell slightly in 2001 to 72,000 (excluding dependants). The trends in asylum applications for selected countries are shown in Chart 4 .

At the same time the number of refugees actually reaching Europe declined between 1992 and 1996, due to interdiction and the imposition of visa requirements. The latter were so drastic that the UNHCR Policy Unit expressed concern that it was becoming almost impossible for genuine asylum seekers to obtain legal entrance to an EU country, forcing people to adopt clandestine methods and to fall victim to unscrupulous traffickers. ${ }^{11}$ However, the number applying for refugee status in Europe has risen again in the last five years. At a summit meeting in June 2002, the EU rejected a hard-line position on asylum seekers proposed by Britain and Spain. The latter would have penalized Third World countries that failed to stem the flow of migrants to Europe. Instead, it was agreed that countries should be given incentives to stop outflows of migrants rather than be punished with cuts to vital aid budgets. Nevertheless, new proposals for joint immigration policing operations at external borders represent another step toward a "Fortress Europe." Exclusionary policies may as-

\section{Chart 3}

Refugees and Others of Concern to UNHCR: 2001

$N=21,793,000$ (includes returnees \& internally displaced)

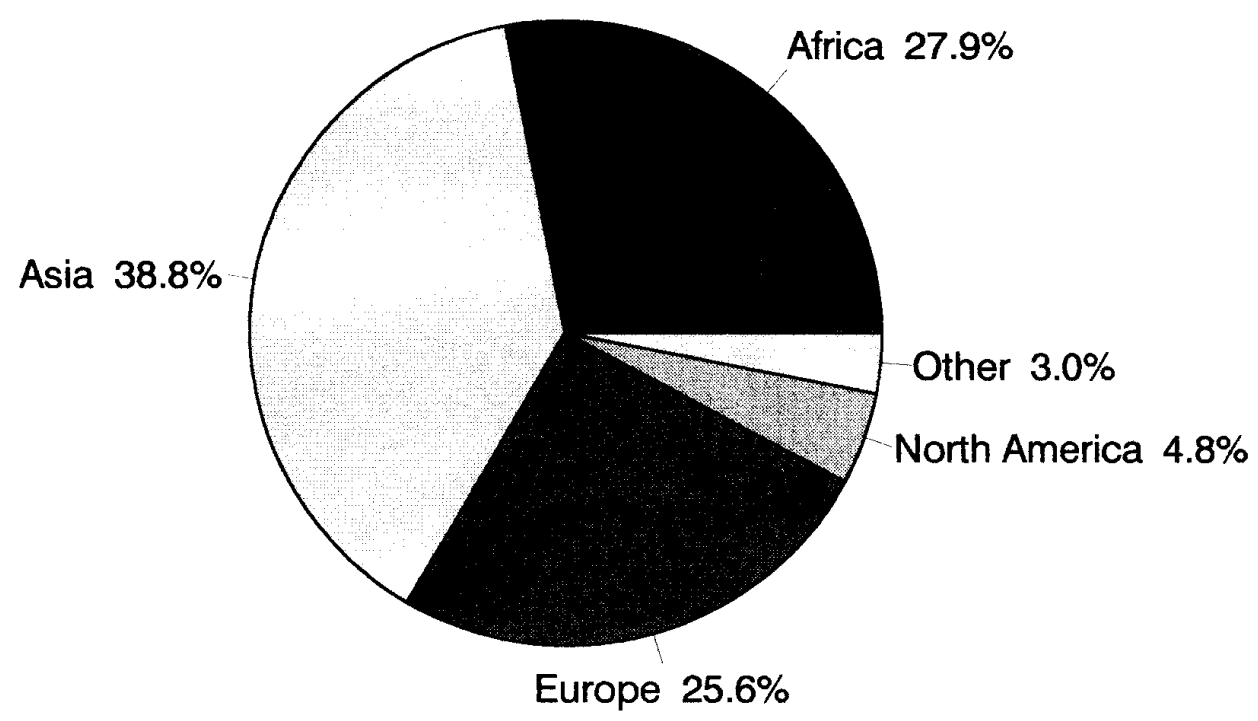

Source: UNHCR (does not include 3.8 million Palestinians in care of UNRWA) 
Chart 4

Asylum Applications: Selected Countries (1992-2001)

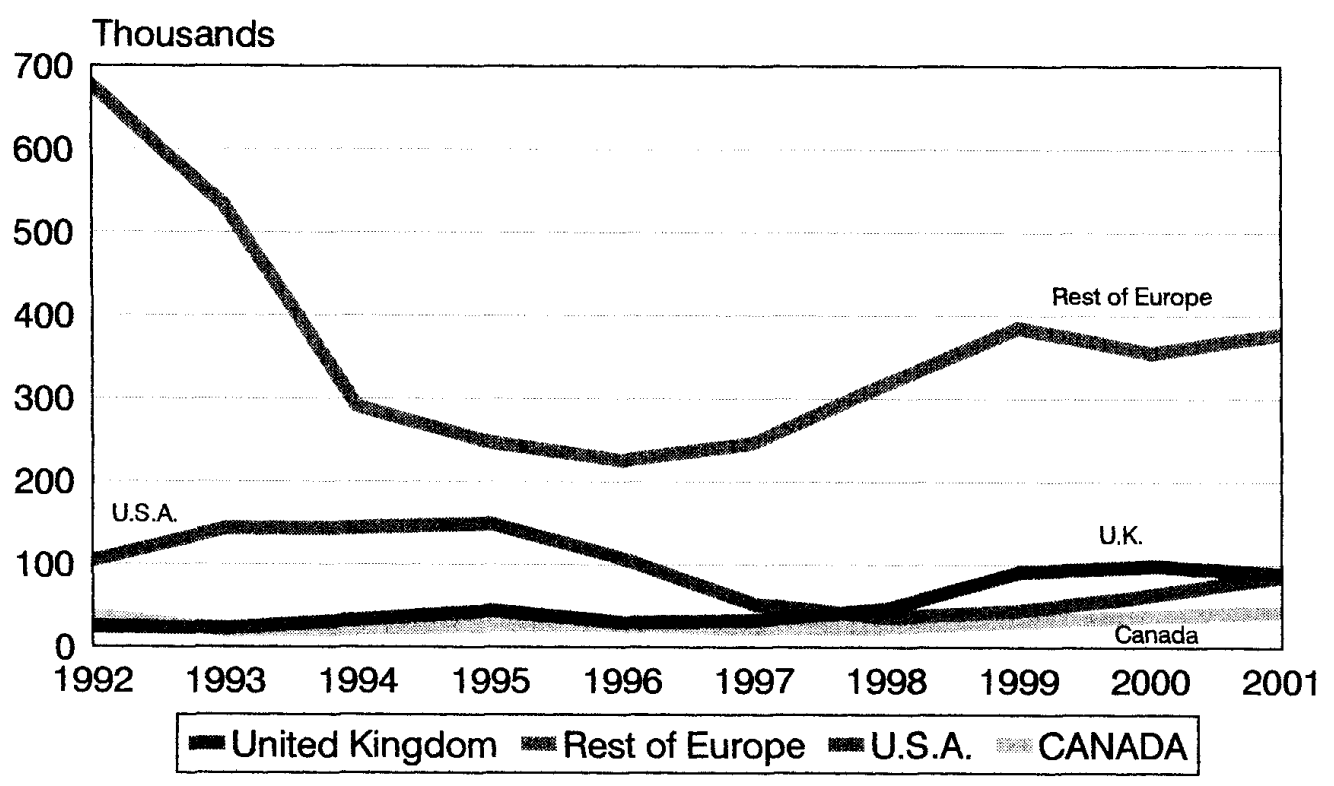

Source: UNHCR Statistical Unit (excludes dependents)

suage the xenophobic Right but they will not solve the problem. There is a need for a common European definition of "asylum seeker," and one that is more rather than less generous than at present.

Governments now use advanced technologies to maintain data banks on suspected terrorists, known criminals, asylum applicants, and alleged "illegal" immigrants. They institute "early warning systems" against mass migration, train airline officials in the checking of documents to facilitate interdiction, and enforce the "non-exodus" of unwanted populations. Electronic fences replace barbed wire and brick walls, while police and soldiers continue to back up immigration officials at borders, and gunboats support the coast guards as they herd people into internment camps, pending repatriation. The exclusion of refugees and asylum applicants recently reached dramatic and tragic proportions in the case of Australia's treatment of "boat people" escaping from Afghanistan and other Asian countries. Last year, several ships were prevented from reaching Australian territory. Instead they were escorted to remote Pacific islands where the UNHCR processed their refugee claims, without any commitment from the Australian government to accept those deemed to be victims of persecution. Asylum applicants who do succeed in reaching Australia are placed in remote camps under conditions that have given rise to hunger strikes, suicide, and other protests. These actions represent an exclusionist approach to refugees and asylum seekers which is at variance with the multicultural policies espoused by previous Australian governments. ${ }^{12}$

Even before the events of 11 September 2001, increased migration pressures, legal and illegal, led to a tightening of regulations in most developed countries, together with new legislation designed to deter migration, interdict undocumented travellers, reinforce border controls, and penalize airlines, shipping companies, and truckers if they are discovered to have knowingly, or unknowingly, carried passengers who do not have a legal right of entry. Canada introduced Bill C-31, which died when an election was called in October 2000. It was reintroduced as Bill C-11 and further amended in 2001. The new law increases the powers of immigration officers to refuse entry to Canada on grounds of criminality, security risk, or forged or inadequate identity documents. It imposes higher maximum penalties for human smuggling, and places the responsibility on airlines to identify and inform Canadian authorities concerning passengers who may be inadmissible to Canada.

Special efforts have been made to punish those involved in the organized smuggling of illegal immigrants across borders. The number of interdictions and removals from Canada has been increasing annually and Bill C-11, when 
fully implemented, will lead to a further increase. It is designed to partially "harmonize" Canada's laws and administrative procedures with those of the United States and other countries. The concept of a "safe third country" has been institutionalized, requiring asylum seekers to apply in the first country they enter after flight from persecution. Whether or not the new immigration law protects the rights of Convention refugees and others will largely depend on how the new regulations are administered and appeals dealt with. A major concern is that people genuinely in need of protection will be forced to return to situations where they risk persecution or serious deprivation.

Various countries have introduced legislation that requires refugees to be fingerprinted, restricts access by asylum applicants to public housing, permits deportation where an asylum claim has been refused, and requires airlines, or other carriers, to ensure that travellers hold a visa to enter, or even to pass through, one country en route to another. Potential refugees must have their asylum claims processed in the first "safe country" they land in. This gives rise to the phenomenon of "refugees in orbit" when no country wishes to accept them. Canada's interpretation of the UN Convention definition of a refugee has been more generous than that of some other countries.

There is growing fear, in Europe and North America, of large-scale economic migration from developing counties, induced by poverty and a sense of relative deprivation compared with the evident affluence of the West. Terrorists' threats and concerns about security have added to these apprehensions. Attempts to limit the flow of illegal economic migrants, refugees, and asylum applicants are part of a growing nostalgia for a less complicated world in which people felt secure in homogeneous communities, where neighbours shared "traditional" values. They are also a reaction to the insecurity felt by many who are faced with a rapidly changing global society. This is evident in the growth of racism, xenophobia, and religious and ethnic conflict in various countries, including those which have traditionally been receptive to both political and economic migrants.

\section{Conclusion}

The world is now a total system experiencing radical structural changes, political, economic, and social. The impact of these changes is particularly evident in respect of transportation, communication, and the transmission of information and pictorial images. However, although money, goods, and services may move relatively freely, people do not. Processes of inclusion and exclusion occur both within and between countries and regions. Irrespective of geographic distance, some individuals and collectivities are fully incorporated into the advanced industrial economy of this emer- ging global system, while others are marginalized or rejected altogether. Feelings of insecurity, and absolute or relative deprivation, lead to prejudice and ethnic conflict and to struggles for power, often precipitating violence.

The power struggle involves not only the boundaries of states, as traditionally understood, but also the boundaries between corporations and states, which are becoming harder to define as governments engage in "trade missions" to promote exports and facilitate transnational investment. Not least among the factors sustaining ethnic conflict and civil war is the hugely lucrative trade in weapons and other military equipment. ${ }^{13}$ At present, the U.S., Britain, Canada, and other OECD countries subsidize their own arms manufacturers and encourage them to export small, intermediate, and powerful weapons, even to those countries engaged in civil war or aggression against their neighbours, giving rise to huge refugee problems.

There is a conflict of interest between those who wish to eliminate borders in the interest of trade and profit, and those who want borders to be reinforced in order to guarantee security from terrorism as well as to deter illegal immigration. In the U.S., Canada, Britain, and the European Union new measures have been introduced to deal with terrorist threats. Ethnic minorities in these countries, irrespective of their legal status in those countries, feel insecure, as do many majority group members faced with the uncertainties of a post-September 11 world. ${ }^{14}$

How is global social exclusion to be combatted? First and foremost, every effort must be made to ensure that the economic benefits of globalization are more equitably spread and that inequalities are reduced, both those within and between countries, regions, and continents. The new global division of labour must benefit the developing world, as well as those who are already wealthy. Within the wealthier countries, regional disparities must be reduced and opportunities found for those who have been left behind by globalization. Humanitarian aid should be increased. No developed country allocates anything like the UN-recommended proportion ( 0.7 per cent) of GNP to assist developing countries. More often than not the assistance is a disguised form of subsidy to the industrialized countries' own corporations seeking export opportunities. The actual percentage is only 0.22 per cent, representing a shortfall of one-hundred billion dollars annually.

Given the pressure to migrate, cross-border population movements must be facilitated through bilateral and multilateral agreements that ensure reciprocity in all dimensions of human rights. As a first step, the ratification of the ILO draft "Convention on the Protection of the Rights of All Migrant Workers and Members of Their Families" by Canada, the U.S., and other industrialized countries is im- 
portant. This would go a long way toward removing some of the abuses currently associated with the employment of temporary workers. ${ }^{15}$ As recommended by the UN Commission on Global Governance, there is a need for a "more comprehensive institutionalized co-operation," or multilateral management of international migration. The positive benefits of migration must be recognized and facilitated. Rather than imposing restrictions that only encourage clandestine migration, governments must facilitate temporary and permanent cross-border movements. Governments must promote a sense of civic pride and citizenship while, at the same time, promoting knowledge and understanding of the world system, or "global neighbourhood," to which we all belong. This calls for "a common commitment to core values that all humanity could uphold: respect for life, liberty, justice and equity, mutual respect, caring and integrity". 16

Above all, we must not allow the panic which followed the terrorist attacks on New York and Washington to result in a closing of borders, a persecution of Islamic or other ethnic minorities, or a diminished concern for human rights, justice, and fairness. There must be respect for UN Conventions and the Charter of Rights. We must ensure the full social inclusion of minorities and marginalized peoples. Ultimately it is a question of belonging, or not belonging, in the emerging world system.

\section{Notes}

1. See European Commission, Communication from the Commission to the Council: Draft Joint Report on Social Inclusion (Brussels: COM, 2001).

2. For example, Anthony Giddens adopted the terminology, insisting that social exclusion is not the same as poverty. He stated, "Social exclusion directs one's attention to the social mechanisms that produce or sustain deprivation." He gives as an example the structural changes in the economy that reduced the demand for unskilled and semi-skilled male labour, as a consequence of deindustrialization and the growth of the service sector. Giddens also suggests that there can be social exclusion at the top, as well as the bottom, of the social ladder. He cites the withdrawal of elites from commitment to their social, economic, and fiscal obligations through retreat into gated, security-conscious communities at home and tax havens abroad. Anthony Giddens, The Third Way and Its Critics (Cambridge: Polity Press, 2000), 104-5.

3. See Anthony H. Richmond, Global Apartheid: Refugees, Racism and the New World Order (Toronto: Oxford University Press Canada, 1994); and "Global Apartheid: A Postscript," Refuge, Vol. 19, no. 4 (2001): 8-13.

4. The Research Centre for Analysis of Social Exclusion (CASE) was established in October 1997 with funding from the Economic and Social Research Council. It is located at the London School of Economics and Political Science. The Labour go- vernment's own research unit on social exclusion is attached to the Cabinet Office.

5. An exception is the "Parekh Report" (the report of the Commission on the Future of Multi-Ethnic Britain, sponsored by the Runnymede Trust) which notes the limitations of the concept when applied to ethnic minorities. Bhikhu Parekh, The Future of Multi-Ethnic Britain (London: Profile Books, 2000), 78-87.

6. L. Platt and M. Noble, Race, Place and Poverty: Ethnic Groups and Low Income (Rowntree York: York Publishing Services for the Joseph Rowntree Foundation, 1999).

7. See The Economist, 15 December 2001, 23.

8. Norman Ouseley, Community Pride and Prejudice: Making Diversity Work in Bradford (Bradford: Bradford Vision, 2001).

9. Ted Cantle, Community Cohesion: A Report of the Independent Review Team (London: Home Office, 2001), 9-10.

10. See Fatima Husain and Margaret O’Brien, "Muslim Communities in Europe: Reconstruction and Transformation," Current Sociology 48, no. 4 (2000): 1-13.

11. John Morrison and B. Crosland, The Trafficking and Smuggling of Refugees: The End Game in European Asylum Policy (Geneva: UNHCR Policy Unit, 2000).

12. See Benjamin Haslem, "Refugees' Treatment Angers Father of Multiculturalism," The Australian 24 (January 2002).

13. In 2001, the UN Conference on Small Arms and Light Weapons failed to gain approval for a clause committing states not to supply small arms and light weapons to non-governmental entities. For a discussion of security issues following 11 September see Ernie Regehr, "Responding to Terror," The Ploughshares Monitor 22, no.3 (2001): 4-7.

14. As Audrey Macklin put it in her contribution to the Conference on Security and Freedom at the University of Toronto: "Boundaries of membership and modes of exclusion can be (and regularly are) redrawn from within the nation. They trace themselves along fault lines that erupt along the surface of our pluralistic, multicultural, democratic country when stressed by real or perceived crisis." Audrey Macklin, "Borderline Security," in The Security of Freedom: Essays on Canada's AntiTerrorism Bill, ed. R.J. Daniels, P. Macklem, and K. Roach (Toronto: University of Toronto Press, 2000), 396.

15. See W.R. Bohning, "The ILO and the New UN Convention on Migrant Workers: The Past and the Future," International Migration Review 24, no.4 (1991): 698-709; and "Protection, International Norms and ILO Migrant Workers Standards," paper presented at the ILO Regional Symposium for Trades Union Organizations and Migrant Workers, 6-8 December 1999.

16. Commission on Global Governance, Our Global Neighbourhood (Oxford: Oxford University Press, 1995), 206-8.

Anthony H. Richmond is Emeritus Professor of Sociology and Senior Scholar, Centre for Refugee Studies, York University, Toronto. 